\title{
Erebia aethiops (Esper, 1777) (Lepidoptera: Nymphalidae) - a new member of the fauna of higher elevations of the Kopaonik mountain
}

\author{
Dejan V. Stojanović \\ University of Novi Sad, Institute of Lowland Forestry and Environment, Novi Sad, Serbia
}

Corresponding author: Dejan V. Stojanović; E-mail: dejanstojanovic021@yahoo.co.uk

Received: 1 Jun 2021; Revised: 7 Jun 2021; Accepted: 17 Jun 2021

\begin{abstract}
Erebia aethiops (Esper, 1777) is an Eurasian butterfly species. Results of the previous studies revealed the presence of only four species belonging to the genus Erebia (Dalman, 1816) on Kopaonik mountain (Mt. Kopaonik), including Erebia ligea (Linnaeus, 1758), Erebia euryale (Esper, 1805), Erebia medusa (Denis \& Schiffermüller, 1775) and Erebia ottomana (Herrich-Schäffer, 1847). A recent finding of the species Erebia oeme (Hübner, 1804) pointed to insufficient research of this group of mountain butterflies on Mt. Kopaonik. This is confirmed by the last finding of Erebia aethiops (Esper, 1777) on two locations at high elevations of Mt. Kopaonik.
\end{abstract}

Keywords: Erebia aethiops, Kopaonik National Park, fauna Lepidoptera, distribution, morphology.

\section{Introduction}

In Eastern Serbia, Erebia aethiops (Esper, 1777) was found for first time on July 20th, 1935, when significant variability of the eyespots of the found specimens was noticed (Živojinović, 1950). The discovery of E. aethiops was included in two monographs of butterflies of Timočka Krajina, including research results from Stol Mt., Tupižnica Mt., and the localities of Stara Planina Mt. (Zečević and Radovanović, 1974; Zečević, 2002).

According to the butterfly's fauna of Serbia (Macrolepidoptera), Erebia aethiops is classified into the family Satyridae (Zečević, 1996). In the comprehensive collection of the distribution maps of butterflies in former Yugoslavia (Lepidoptera: Rhopalocera), beside the localities of findings in East Serbia, the numerous localities in west and south-western Serbia are also comprised and presented (Jakšić, 1988). However, Popović and Đurić (2011) missed out the locality on Avala, cited by former author, and added the findings on the Vlasinsko jezero lake and Golija Mt. The list of localities in western Serbia has been recently enriched by the finding on Jadovnik Mt. (Jakšić, 2020). On Fruška Gora Mt. and in north Serbia on a whole, the species was not recorded (Popović and Đurić, 2011; Stojanović and Ćurćić, 2014). This fact confirms the rule that the species does not belong to the fauna of butterflies which is presented on lower elevations.

The comprehensive entomological research of Kopaonik Mt. revealed presence of only four species from genus Erebia Dalman, 1816: Erebia ligea (Linnaeus, 1758), Erebia euryale (Esper, 1805), Erebia medusa (Denis and Schiffermüller, 1775) and Erebia ottomana (Herrich-Schäffer, 1847) (Jakšić and Đurić, 
2007; Jakšić and Nahirnić, 2013). Additionally, although with a neglected focus on the butterflies, a complex long-term research of the higher parts of Kopaonik (2009-2019) revealed the presence of additional species - Erebia oeme (Hübner, 1804) (Stojanović and Šumarac, 2020).

A great number of Erebia aethiops variations is recorded in the literature (Leraut, 2016). Also, the same author showed the species distribution range identical to those previously reported by Popović and Đurić (2011). Two subspecies are cited by Tshikolovets (2011). One of them is present in Europe (with the similar distribution range like aforementioned authors reported), whereas the second one is presented in Caucasus. Shortened distribution list from the previous ones is given by Lafranchis (2000), while Fauna Europaea (de Jong et al. 2014) evidenced that this species occupies almost the entire Europe.

Climate changes have caused great environmental changes worldwide, thus allowing that many species got the opportunity to conquest new territories. The distribution expansion of the species Erebia aethiops represents a possible example. During the last forty years, the areal of species distribution has been expanded from European central and eastern areas (Higgins and Riley, 1984) to the south and west (Leraut, 2016). The list of existing and possible habitats of genus Erebia in the Republic of Serbia is presented by Jakšić et al. (2008).

\section{Material and methods}

The research has been conducted during warm, sunny days in July and August, 2019 and 2020. The author of the paper collected the specimens by the entomological net. The butterflies were sampled on forest clearings, along forest roads and on subalpine meadows. An UTM code is given for each investigated locality. The collected adults were afterwards stored as dry specimens in entomological boxes in the private collection of the author. Identification was conducted according to Leraut (2016).

The photographs of localities were made by using a Canon EOS 5D digital camera, equipped with CANON lens EF $50 \mathrm{~mm}, 1: 1,8 \mathrm{~L}$. The photographs of insect specimens and genital armature were made by the same digital camera, equipped with CANON macro lens EF $100 \mathrm{~mm}, 1: 2,8 \mathrm{~L}$. The photographs of prepared specimens given below were taken in the laboratory of the Institute of Lowland Forestry and Environment, University of Novi Sad.

\section{Results and discussion}

\subsection{Distribution}

Erebia aethiops (Esper, 1777) is a Eurasian butterfly species. According to the Fauna Europaea (de Jong et al. 2014), the species is present almost in the entire Europe, except of its southernmost, southeastern and northernmost parts (e.g. Spain, Portugal, Turkey, Malta, Moldova, Denmark and Nordic countries).

Records of E. aethiops at the National Park „Kopaonik“ are reported at the localities Kukavica and Đorov most, which belong to UTM squares DN 79 and DP 70, respectively (marked on Figure 1a). The map with localities of findings and UTM grids are given in Figure 1. In 2019, three male specimens were found on the locality Kukavica, in the period from $2^{\text {nd }}$ to $9^{\text {th }}$ August. The altitude of the locality amount $1705 \mathrm{~m}$ a.s.l. (Figure 1b). Also, two male specimens were found on the locality Đorov most in the period from $6^{\text {th }}$ to $10^{\text {th }} \mathrm{July}, 2020$. The altitude of this locality is $820 \mathrm{~m}$ a.s.l. (Figure 1c). E. aethiops is characterized by the flight period during July and August, during which it produces one generation.

\subsection{Morphological description and biology}

The wingspan of the species is $35-42 \mathrm{~mm}$. Wings blackish brown. Forewing dotted with postdiscal line orangey brown, with three eyespots encircled with black showing white pupils. 
Hindwing with very narrow line, quite indistinct, with three very small eyespots (Figure 2-left). Ventral side: forewing brown, hindwing with base and postdiscal line grey-brown (Figure 2-right).

Male genital armature: outer horns of uncus truncate; valve pointed, a small costal shoulder and narrow apex dentate, both with small teeth and larger teeth may be present on shaft; penis straight, stout. Juxta elongated, dentated. Vinculum triangular, convex at the bottom (Figure 3).

Main host plants: Agrostis canina, Anthoxanthum odoratum, Brachypodium pinnatum, Briza media, Bromus erectus, Calamagrostis epigejos, Carex sempervirens, Dactylis glomerata, Festuca ovina, Luzula nivea, Molinia caerulea, Poa trivialis, Poa annua, Sesleria caerulea (Tshikolovets, 2011).
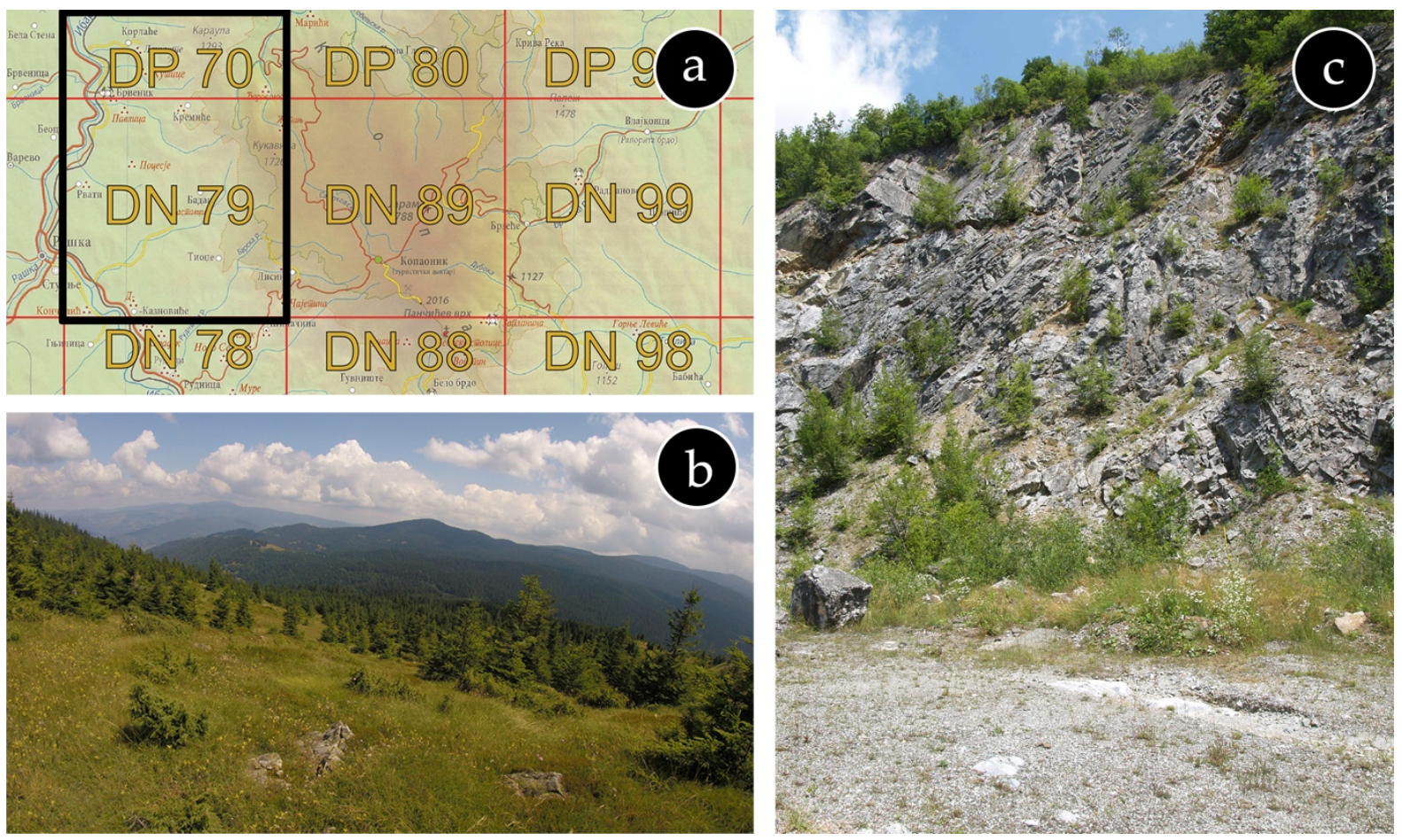

Figure 1. a) Map of localities in the National Park „,Kopaonik” with UTM grids, b) the locality Kukavica (1705 $\mathrm{m}$ a.s.l.), and c) the locality Đorov most (820 m a.s.l.) (photos: Stojanović, D.V.).
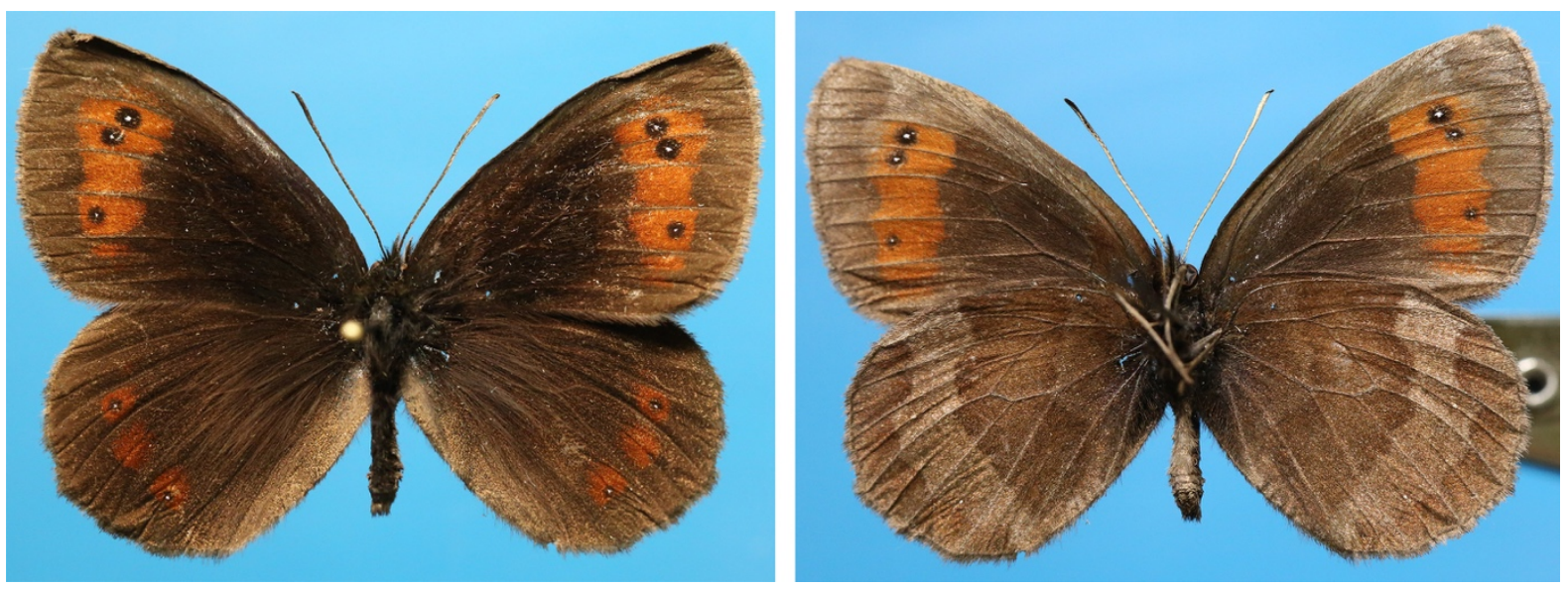

Figure 2. Erebia aethiops, habitus of adults - spread wings (dorsal view) (left) and spread wings (ventral view) (right) (photo: Stojanović, D.V.) 


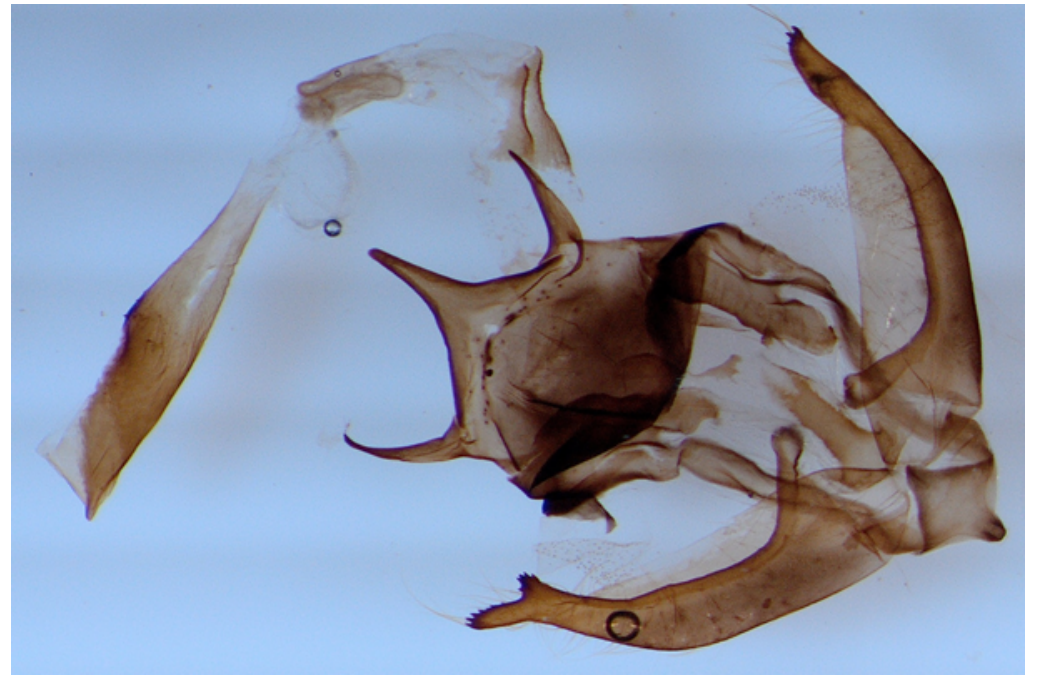

Figure 3. Erebia aethiops, the male genital armature (photo: Stojanović, D.V.)

\section{Conclusion}

With this finding, the fauna of the genus Erebia (Lepidoptera: Nymphalidae) of the National Park "Kopaonik" has increased on six species, in total. Earlier researches revealed only four species from genus Erebia (E. ligea, E. euryale, E. medusa and E. ottomana) on the mountain Kopaonik. The recent finding of the species Erebia oeme (Stojanović and Šumarac, 2020) has indicated a lack of studies of this group of mountain butterflies at the "Kopaonik" National Park. This has been proven with the finding of Erebia aethiops (Esper, 1777) on two locations in 2019 and 2020 in the higher parts of Mt. Kopaonik. Therefore, the discovery of new species from this genus might be expected in the future.

\section{Acknowledgement}

This study was financed by the Ministry of Education, Science and Technological Development of the Republic of Serbia (Contract No. 451-03-9/2021-14/200197).

\section{References}

1. de Jong, Y., Verbeek, M., Michelsen, V., Bjørn, P., Los, W., Steeman, F., Bailly, N., Basire, C., Chylarecki, P., Stloukal, E., Hagedorn, G., Wetzel, F., Glöckler, F., Kroupa, A., Korb, G., Hoffmann, A., Häuser, C., Kohlbecker, A., Müller, A., Güntsch, A., Stoev, P., Penev, L. (2014): Fauna Europaea - all European animal species on the web. Biodiversity Data Journal 2: e4034.

2. Higgins, L.G., Riley, N.D. (1984): A field guide to the butterflies of Britain and Europe. Fifth edition. Collins. London.

3. Jakšić, P. (1988): Privremene karte rasprostranjenosti dnevnih leptira Jugoslavije (Lepidoptera: Rhopalocera). Posebno izdanje, Sveska 1. Jugoslavensko entomološko društvo. Zagreb.

4. Jakšić, P. (2020): Dnevni leptiri Jadovnika. Mileševke i susednih područja (Lepidoptera: Papillionoidea). Prirodnjački muzej u Beogradu, posebna izdanja, Knjiga 47.

5. Jakšić, P., Đurić, M. (2007): Vodič kroz faunu dnevnih leptira Kopaonika. Nacionalni park "Kopaonik". Kopaonik.

6. Jakšić, P., Nahirnić, A. (2013): Vodič kroz faunu dnevnih leptira Kopaonika (Lepidoptera: Hesperioidea i Papilionoidea). Nacionalni park "Kopaonik". Kopaonik.

7. Jakšić, P., Verovnik, R., Dodok, I. (2008): Overview of prime butterfly areas in Serbia. In: Jakšić, P. (Ed.). Prime butterfly areas in Serbia. HabiProt. Belgrade. pp. 43-200.

8. Lafranchis, T. (2000): Butterflies of Europe. Diatheo. Paris. 
9. Leraut, P. (2016): Butterflies of Europe and neighbouring regions. N.A.P. Editions. Verrieresle-Buisson.

10. Popović, M., Đurić, M. (2011): Dnevni leptiri Srbije: priručnik. HabiProt. Beograd.

11. Stojanović, D.V., Ćurčić, S.B. (2014): Fauna Lepidoptera Nacionalnog parka “Fruška gora”. Deo I: Dnevni leptiri. Institut za nizijsko šumarstvo Univerziteta u Novom Sadu i Nacionalni park "Fruška gora". Novi Sad.

12. Stojanović, D.V., Šumarac, P. (2020): Fauna Lepidoptera Nacionalnog parka "Kopaonik", Deo I: 300 leptira Visokog Kopaonika. Institut za nizijsko šumarstvo i Nacionalni park "Kopaonik". Raška-Novi Sad.

13. Tshikolovets, V.V. (2011): Butterflies of Europe \& the Mediterranean area. Tshikolovets Publications. Pardubice.

14. Zečević, M. (1996): Pregled faune leptira Srbije (Macrolepidoptera). Institut za istraživanja u poljoprivredi. Beograd.

15. Zečević, M. (2002): Fauna leptira Timočke krajine (istočna Srbija). DŠIP „Bakar“ i Narodni muzej u Zaječaru. Bor-Zaječar.

16. Zečević, M., Radovanović, S. (1974): Leptiri Timočke Krajine. Zavod za poljoprivredu. Zaječar.

17. Živojinović, S. (1950): Fauna insekata šumske domene Majdanpek. Entomološka monografija. Knjiga CLX (2). Institut za ekologiju i biogeografiju SANU. Beograd. 